\title{
Structural features off southwestern Taiwan
}

\author{
Char-Shine Liu ${ }^{a, *}$, Ian L. Huang ${ }^{b}$, Louis S. Teng ${ }^{c}$ \\ ${ }^{a}$ Institute of Oceanography, National Taiwan University, Taipei, Taiwan, R.O.C. \\ bepartment of Geology, Chinese Culture University, Taipei, Taiwan, R.O.C. \\ ' Department of Geology, National Taiwan University, Taipei, Taiwan, R.O.C.
}

Received 5 August 1995; accepted 11 November 1996

\begin{abstract}
Seismic reflection profiles reveal a complex system of faults, mud diapirs, submarine channels, and sedimentary basins in the offshore area southwest of Taiwan. Structural patterns demonstrate the on-going structural transformation from the passive Chinese continental margin to the Taiwan collision orogen. The boundary between the Chinese continental margin and the Taiwan orogen can be clearly delineated by the deformation front of the contractional structures. West of the deformation front, ENE-WSW trending normal faults prevail in the continental margin, which is characterized by a horst-and-graben structural style. East of the deformation front, west-vergent imbricated folds and thrusts sheets abound in the accretionary wedge. The structural grain of the accretionary wedge trends NNW-SSE in the deep offshore area but bends toward NNE-SSW in the shallow near shore area. Mud diapirs emerge through thick sedimentary layers forming NNE-SSW trending anticlines that extend from near shore areas to onland Taiwan. Mud volcanoes have been observed on $3.5 \mathrm{kHz}$ profiles over several diapirs. Structural styles observed across the frontal portion of the submarine Taiwan accretionary wedge are strongly controlled by the tectonic evolution of the arc-continent collision. The structure and location of the deformation front are affected both by the growth of the accretionary wedge and by the geometry of the Chinese continental margin basement.
\end{abstract}

Keywords: seismic imaging; arc-continent collision; Taiwan; continental margin; accretionary wedge; deformation front

\section{Introduction}

The island of Taiwan is located at the juncture of the Ryukyu and Luzon island arcs along the western margin of the Philippine Sea. South of Taiwan, the South China Sea lithosphere is subducting eastward under the Luzon arc. East of Taiwan, the Philippine Sea plate is subducting northward under the Ryukyu arc (Fig. 1). The

* Corresponding author. P.O. Box 23-13, Taipei, Taiwan, R.O.C. Tel: (886-2)366-0881, Fax: (886-2)362-6092, E-mail: csliu@ccms.ntu.edu.tw
Taiwan mountain belt is formed by the late Cenozoic collision of the Luzon arc with the Asian continent (Biq, 1972; Chai, 1972; Bowin et al., 1978; Ho, 1986; Teng, 1990). The structural grain of the Taiwan mountain belt trends NNE-SSW, forming an arc convex toward the Asian continent (Fig. 1). Onland Taiwan, the orogenic structural features are well demonstrated by a series of stacked folds and thrust sheets verging west (Ho, 1982). These orogenic structural features are believed to extend southward to offshore southwestern Taiwan (e.g. Letouzey and Sage, 1988). However, as they are buried by the thick 


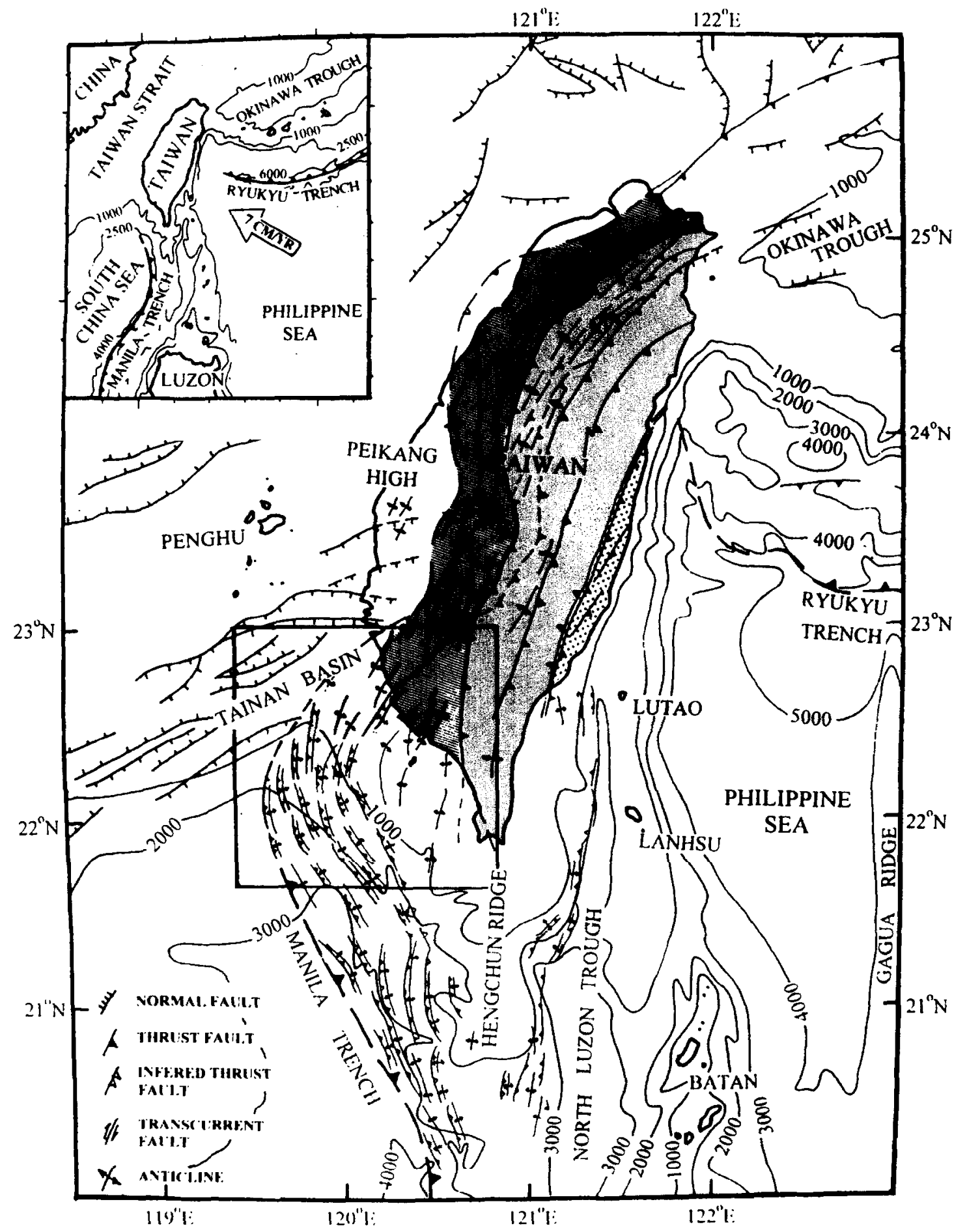

Fig. 1. Structural map of Taiwan and adjacent area. Isobaths in meters. Square block shows the structural features from this study. Structures onland Taiwan and in the Taiwan Strait region are modified from Letouzey and Sage (1988). Structures of the Luzon accretionary prism outside study area are from Reed et al. (1992). Main structural units of Taiwan from east to west are: the Coastal Range (dotted area), the Central Range (light-shaded area), the Western Foothills (heavy-shaded area), and the Coastal Plain (plain area). Inset shows the tectonic setting of Taiwan and two adjacent subduction systems. Vector of relative motion hetween the Philippine Sea plate and the Eurasia plate as open arrow. Isobaths in meters. 
Quaternary sediments, the structural patterns of offshore southwestern Taiwan remain largely unknown.

According to a recent marine geophysical survey (Lundberg et al., 1991, 1992; Reed et al., 1992; Liu et al., 1992), the Manila Trench shallows toward the Chinese continental margin in a NNW direction and terminates at about $21^{\circ} 30^{\prime} \mathrm{N}$. The accretionary wedge widens northward from about $70 \mathrm{~km}$ south of $20^{\circ} \mathrm{N}$ to over $110 \mathrm{~km}$ near the southern tip of Taiwan. Two structural domains have been recognized on the trench side of the accretionary wedge: a lower slope domain which is composed of NNW-trending, mostly W-vergent ramp anticlines and thrusts, and an intensely deformed, mostly reflection-free upper slope domain (Reed et al., 1992). Morphologically, the upper slope domain of the submarine accretionary wedge extends northward to the Central Range of Taiwan. The lower slope domain of the submarine accretionary wedge should continue northward to become the fold-and-thrust belt of the Western Foothills of Taiwan. However, it is not clear in previous surveys that how the NNE-SSW trending folds and thrusts of the Western Foothills are related to the NNW-SSE trending similar structures observed in the lower slope domain of the submarine accretionary wedge.

Furthermore, previous studies have proposed different ways of connecting the Manila Trench to a structure onland Taiwan that delineates the boundary between the subducting Eurasian plate and the overriding Philippine Sea plate. For example, Biq (1972) suggested that the Manila Trench should connect northward to the Longitudinal Valley east of the Central Range. On the other hand, Bowin et al. (1978) suggested that the Manila Trench connects to the onland thrust structures in the southwestern Taiwan near Kaohsiung. Lu and Hsu (1992) put the plate boundary to the west of the Central Range along the Lishan and Laonungchi (Chaochou) Faults which extends southward and eventually connects to the Manila Trench. Due to lack of marine geophysical data, even the surface location of the plate boundary has been controversial. Suppe (1984), Ho (1986) and Teng (1990) generally followed the surface plate boundary of Bowin et al. (1978), but
Letouzey and Sage (1988) and Lundberg et al. (1991) have indicated that the northern extension of the Manila Trench may extend further west into the Penghu Channel. All these arguments demonstrate the importance of the structural geology of offshore southwest Taiwan to the understanding of the regional tectonic configuration.

In order to investigate the relationships between the onland structures and their offshore counterparts in southwestern Taiwan, marine geophysical surveys have been carried out in the area off southwestern Taiwan between $22^{\circ} \mathrm{N}$ and $23^{\circ} \mathrm{N}$ (Fig. 1) in the last four years by the Institute of Oceanography, National Taiwan University. This paper presents the preliminary results from that four-year investigation, focusing mainly on the structural features observed from the seismic reflection profiles. The results suggest that large amount of incoming orogenic sediments from the Taiwan mountain belt has caused rapid outward growth of the accretionary wedge and westward migration of the deformation front. The basement relief of the Chinese continental margin played an important role in shaping the structures of the deformation front.

\section{Bathymetry and seismic data}

A bathymetry map of the study area derived from the newly compiled digital bathymetry data base of offshore Taiwan (Liu et al., 1996) is shown in Fig. 2. Crossover error analyses of the bathymetry data at intersecting ship tracks have been performed to assure the quality of the data used in the compilation. Major morphological provinces shown in the map include the Taiwan Strait shelf, the South China Sea slope, the Kaoping shelf, and the Kaoping slope (named after $\mathrm{Yu}$ and Wen, 1992). The Manila Trench is observed in the southwestern corner of the study area. At about $21^{\circ} 30 \mathrm{~N}$, the Manila Trench loses its morphological character and connects to the Penghu Channel further north. Submarine canyons, such as the Kaoping and the Fangliao submarine canyons, are prominent features on the bathymetry map. Their physiographic characteristics and developments have been reported by Liu et al. (1993) and Yu 


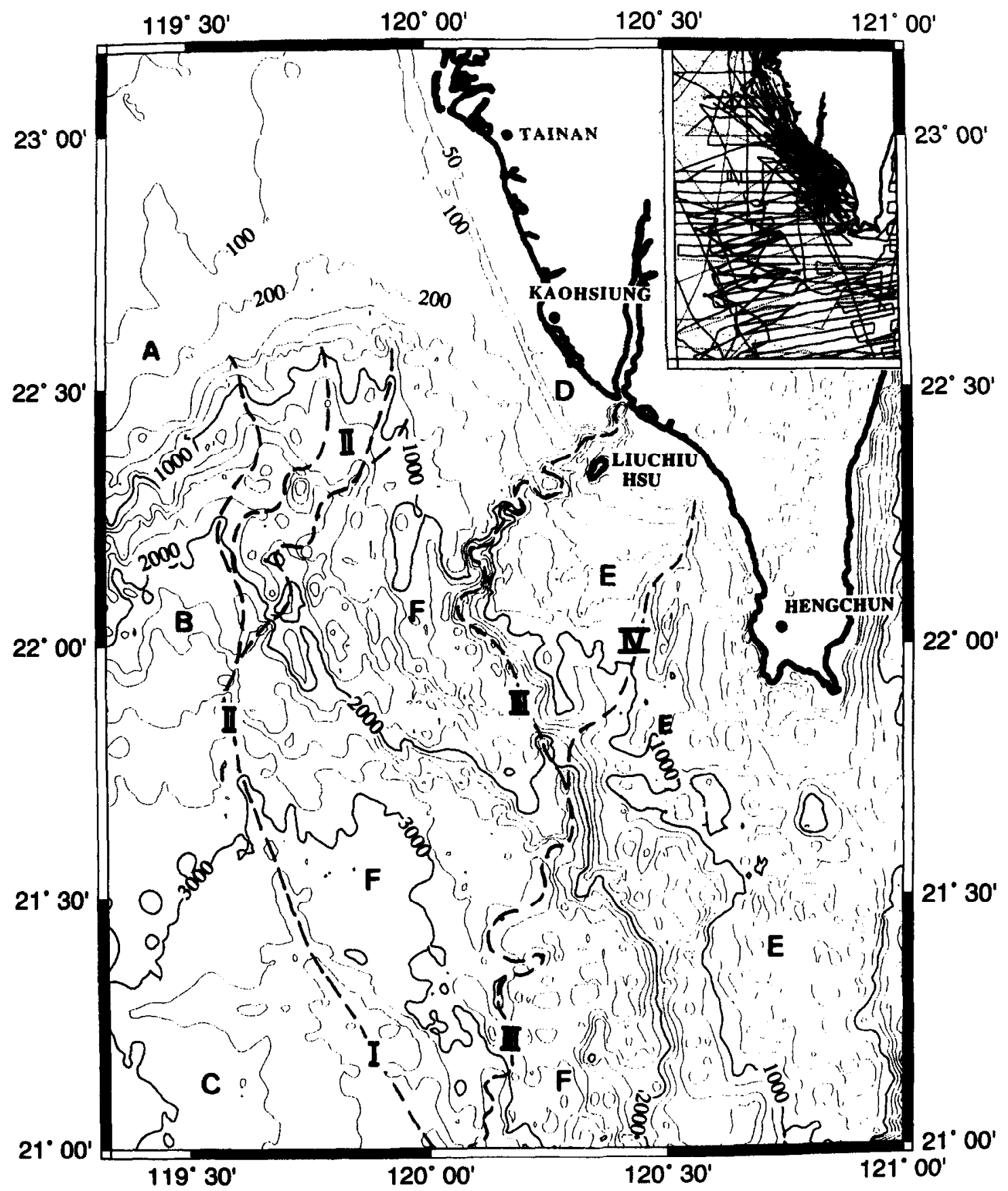

Fig. 2. Bathymetry map of the study area. The bathymetric data were grided and contoured using the GMT system (Wessel and Smith, 1991). Contour interval is $200 \mathrm{~m}$ except in the shelf area where 50 and $100 \mathrm{~m}$ contours are given. Major morphological units are: $A=$ Taiwan Strait shelf; $B=$ South China Sea slope; $C=$ South China Sea basin; $D=$ Kaoping shelf; $E=$ Upper slope domain of the Kaoping slope; $F=$ Lower slope domain of the Kaoping slope. Dashed lines indicale the locations of the Manila Trench $(I)$, the Penghu Channel system $(I I)$, the Kaoping Submarine Canyon $(I I I)$, and the Fangliao Submarine Canyon (IV). Inset shows the tracklines where the bathymetric data have been collected. 
and Liu (1996). The Penghu Channel marks the boundary between the Kaoping slope and the South China Sea slope.

Marine seismic reflection data have been collected using the $R / V$ Ocean Researcher $I$ of the National Taiwan University. Seismic sources used in the surveys were airgun arrays consisting of 3 Bolt airguns. The maximum output volume of the airgun array was $920 \mathrm{in}^{3}$ (using one $500 \mathrm{in}^{3}$, one $300 \mathrm{in}^{3}$ and one $120 \mathrm{in}^{3}$ airgun), the air pressure was maintained at 2000 psi. Both single-fold (using either a 2-channel or a 4-channel streamer) and multifold (using either a 24-channel or a 60-channel streamer) seismic reflection data were collected in digital form. Multichannel seismic data from cruises ORI265, ORI270, and ORI286 were processed at the Geophysical Data Processing Center of the Chinese Petroleum Corporation using the DISCO scismic data processing systcm. All the other seismic reflection data were processed at the Institute of Oceanography, National Taiwan University using the SIOSEIS seismic data processing software. Detailed description of the seismic data acquisition and SIOSEIS processing systems were given in Liu (1992).

\section{Structural framework}

The area offshore southwestern Taiwan is the place where the passive Chinese continental margin first encroaches on the Taiwan mountain belt. Fig. 3 summarizes major structures of the study area. Due to limitcd coverage of the seismic lines over the Taiwan Strait shelf area, the trends of the normal faults in that area were based on Tsao and Chang (1988). The distribution of structural patterns clearly demonstrates the on-going structural alteration from a passive to an active tectonic environment: ENE-WSW trending normal faults which represent the rifted Chinese continental margin structure are observed mainly in the northwestern portion of the study area, while fold-andthrust structures which represent subduction-collision zone are located in the central and southern portions of the study area. The boundary that separates these two distinctive structural domains is the deformation front of the Taiwan mountain belt.

The structure of the Chinese continental margin in this area (the Tainan Basin) is characterized by a horst-and-graben system related to the extensional tectonics of the passive Chinese continental margin (Sun, 1982, 1985; Hu, 1988). The PlioPleistocene deposits thicken from NE to SW, indicating that the Plio-Pleistocene arc-continent collision has transformed the Tainan Basin from a passive margin setting into a foreland setting (Lee et al., 1993).

The extensional structures of the Tainan Basin extend northeasterly to the Coastal Plain of southwestern Taiwan where they are terminated by NNE trending fold-and-thrust structures of the Western Foothills. These contractional structures are covered by thick alluvial deposits of the Coastal Plain and Pingtung Valley in the coastal arca of southwestern Taiwan (Pan, 1968; Hsieh, 1972; Bonilla, 1977; Hsu and Chang, 1979; Kuang and Wu, 1986). Seismic reflection profiles collected in the offshore Tainan-Kaohsiung-Hengchun area reveal widely distributed NNE-SSW trending diapiric anticlines (Huang, 1993; Sun and Liu, 1993; Huang, 1995). Many of these anticlinal structures extend northward and connect to similar structures of onland southwestern Taiwan (Huang, 1995).

\section{Chinese continental margin}

Seismic characteristics of the Taiwan Strait shelf strata along the Chinese continental margin gencrally cxhibit continuous coherent reflections with parallel to divergent patterns (Fig. 4A). Normal faults cut through most of the observable sedimentary sequences (over 3 seconds two-way traveltime) to form asymmetric horsts and grabens. The regional structural trend has been suggested to be ENE-WSW (Sun, 1982, 1985; Hu, 1988; Tsao and Chang, 1988), though Yang et al. (1994) proposed a two-stage model for faulting in the Tainan Basin. They suggested that a NE-SW trending normal fault system was developed from Late Oligocene to Late Miocene due to the post-rift subsidence that preceded the opening of the South China Sea. The second stage of the extensional 


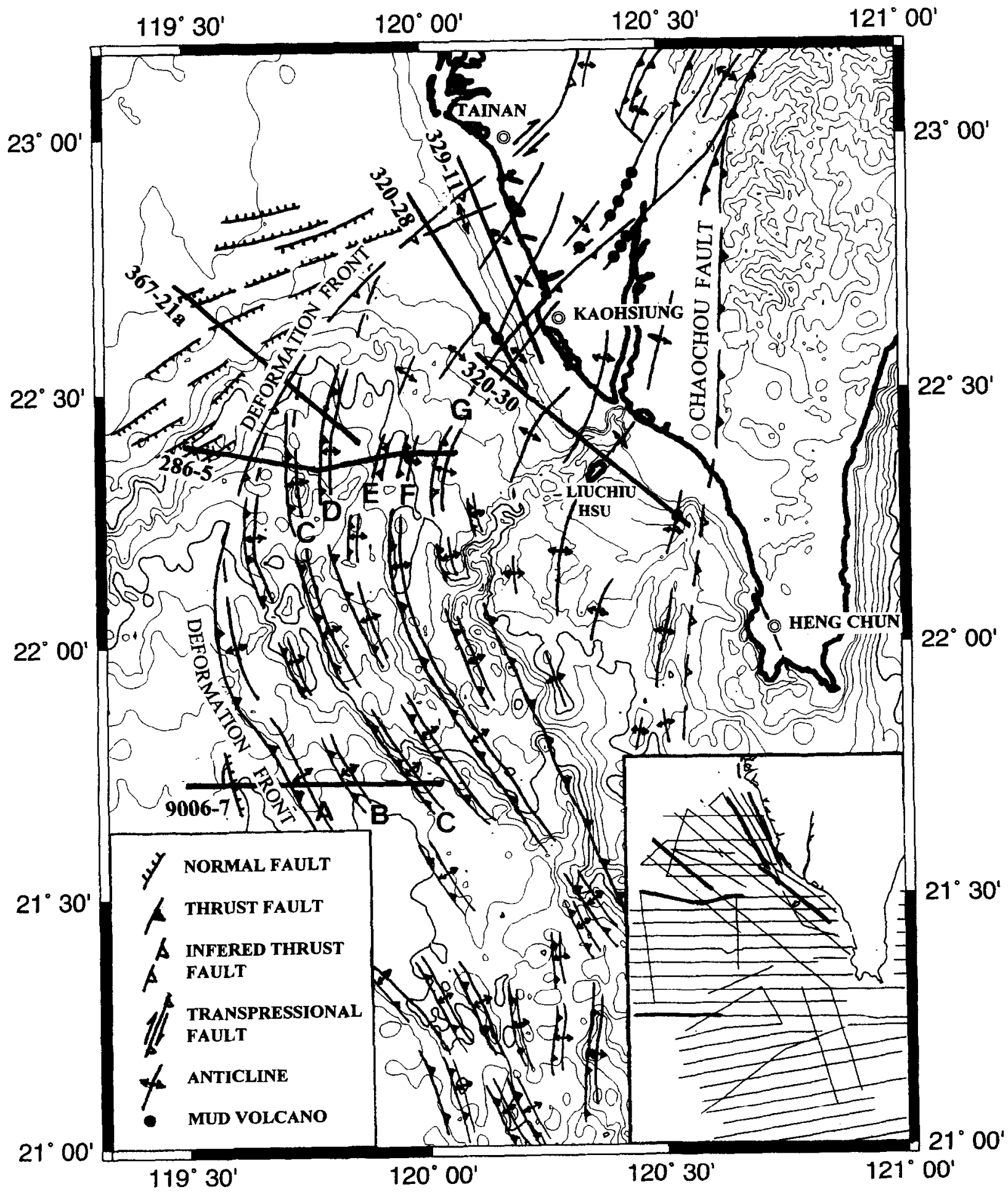

Fig 3. Structural map of the study area. Bathymetric contours (in meters) are shown in thin lines. Thick lines with numbers indicate the locations of the seismic profiles shown in Figs. 4, 5, and $7 . A-G$ indicate the fault-bend-fold structures discussed in the text. Structures onland Taiwan are mainly based on the geological maps published by the Chinese Petroleum Corporation (1971, 1989). Inset shows the tracklines wherc seismic reflection profiles have been used for structural compilation. 
(A) $367-21 \mathrm{a}$
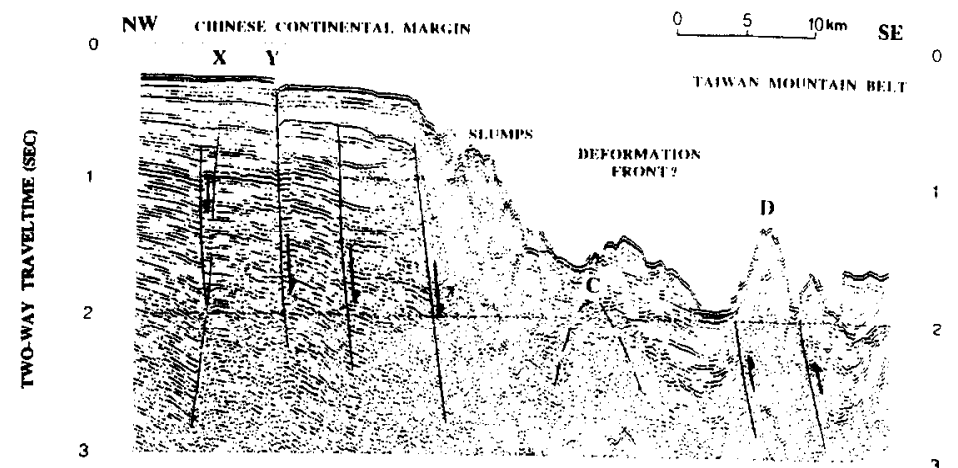

(B) 286-5

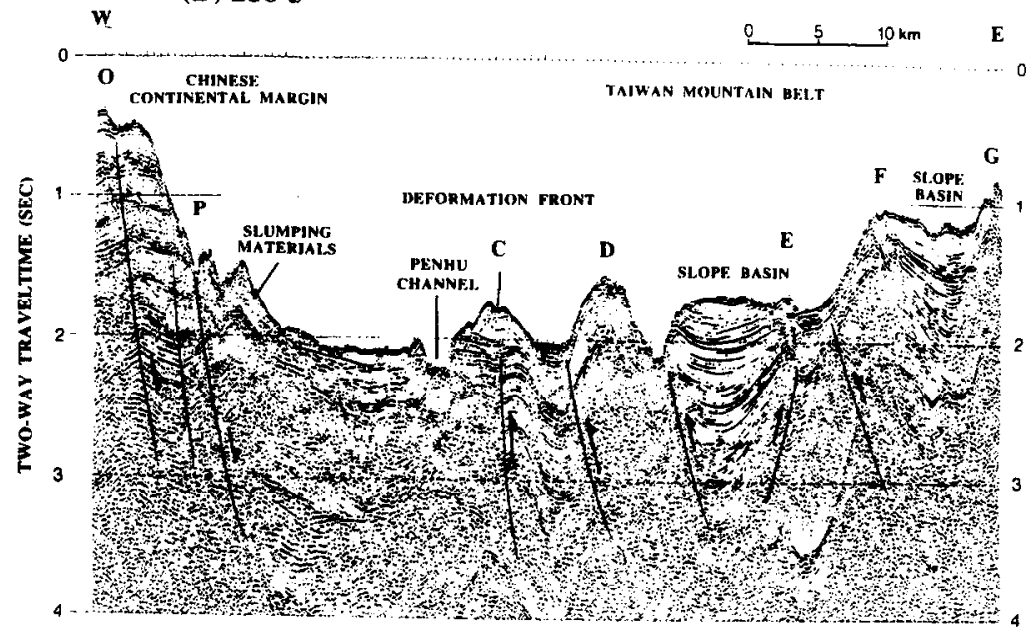

(C) 9006-7

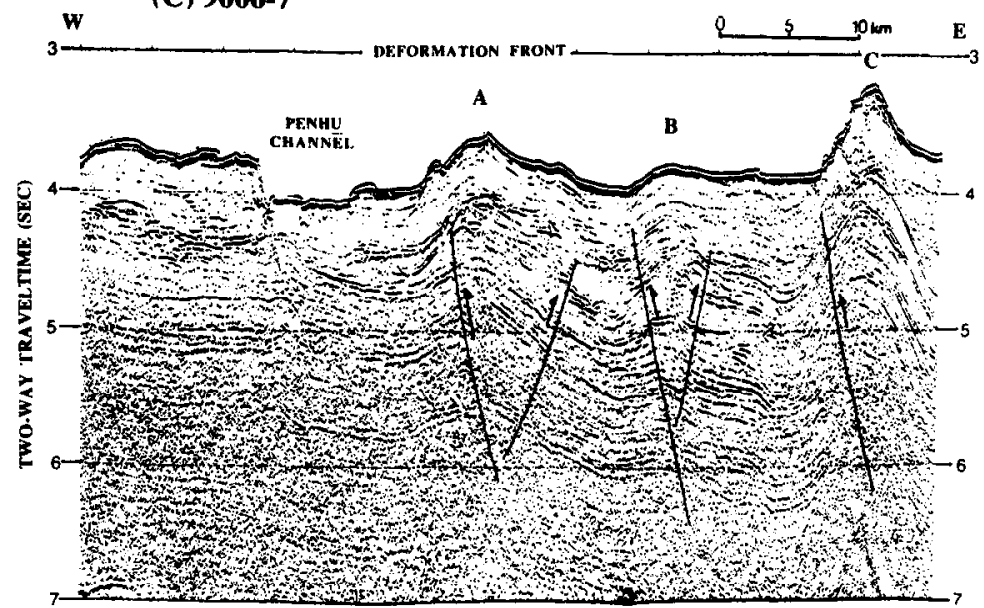

Fig. 4. (A) Migrated single-fold seismic profile 367-21a. Location is given in Fig. 3. $X$ and $Y$ indicate the locations of normal faults on the Chinese continental margin. $C$ and $D$ are anticlinal features which could be correlated to structures $C$ and $D$, respectively, of profile 286-5. (B) Migrated multichannel seismic reflection profile 286-5. Location is given in Fig. 3. $C-G$ are prominent ramp anticlines which could be correlated to similar structures on the adjacent profiles. (C) Migrated 4-fold seismic profile 9006-7. Location is given in Fig. 3. $A-C$ are almost evenly spaced ramp anticlines. $C$ could be correlated to the structure $C$ in profile 286-5. However, structure $B$ is not identifiable underneath the slope sediments in profile $286-5$. 
tectonics started in Late Miocene and has continued to the present. The structures developed during this stage are characterized by discrete E-W trending normal fault segments (Yang et al., 1991). Our seismic profiles are too sparse in the Tainan Basin area to delineate the trend of the normal faults.

A NW-SE trending seismic profile (Fig. 4A) reveals typical extensional structures of the passive Chinese continental shelf and slope. Sedimentary strata thicken toward the SE. A NW-dipping normal fault located near the $\mathrm{NW}$ end of the profile (location $X$ in Fig. 4A) may be related to a major fault system (the $B$ fault of Tsao and Chang, 1988) which marks the northern boundary of the Central High in the Tainan Basin. A series of SE-dipping normal faults cuts across the southern portion of the Central High. One normal fault extends upward to the sea floor (location $Y$ in Fig. 4A), indicating recent fault activity.

Seismic reflections become chaotic and exhibit very poor continuity within the continental slope material. A major NE-SW trending boundary fault (the E Fault of $\mathrm{Hu}, 1988$ ) has been suggested to separate the Central High from the Southern Depression (Hu, 1988; Tsao and Chang, 1988; Si-Chih Sun, pers. comm., 1993). The abrupt change of seismic characteristics from a coherent to a chaotic pattern may indicate the location of this SW-dipping normal fault. Slump deposits on the surface of the slope and inadequate source energy used during seismic data acquisition hinder the observation of deeper structure underneath the slope area.

\section{Accretionary wedge}

The lower and the upper slope domains of the submarine accretionary wedge off southern Taiwan can be extended into the study area offshore southwest Taiwan (Reed et al., 1992). The upper slope domain includes the Kaoping slope and Kaoping shelf area east of the Fangliao Canyon. The lower slope domain roughly includes the Kaoping slope and Kaoping shelf area between the Penghu Channel and the Fangliao Canyon (Fig. 2). The lower slope domain structures are discussed below.

Fig. 4B,C shows two E-W trending seismic pro- files across the frontal portion of the accretionary wedge. Located from south to north (Fig. 3), these two profiles together with profile 367-21a (Fig. 4A) demonstrate the change of frontal structures of the accretionary wedge as it approaches the Chinese continental margin.

The southern profile 9006-7 (Fig. 4C) running across the northern extension of the Manila Trench reveals the detailed frontal structure of the Luzon accretionary wedge. Imbricated thrusts and related folds are the most prominent features observed in the lower slope domain of the submarine accretionary wedge. East of the bathymetric low lie a series of W-vergent anticlines (structures $A-C$ in Fig. 4C) formed over thrust ramps. The spacing between adjacent ramp anticlines is about $12 \mathrm{~km}$. Ramps progressively steepen eastward, suggesting increasing deformation of accreted strata toward east.

Fig. 4B presents a seismic protile across both the Chinese continental margin and the accretionary wedge of the Luzon subduction-collision system. Over the Chinese continental margin, eastdipping normal faults (location $O$ in Fig. 4B) and slump deposits (location $P$ in Fig. 4B) are similar to features observed in Fig. 4A. East of the bathymetric low where the Penghu Channel cuts through the surface sediment, anticlinal folds underlain by thrust ramps (structures $C-G$ of Fig. 4B) clearly represent the compressional structural patterns of an active tectonic regime. Most of the anticlines show a steeper western flank, suggesting that the underlying thrust ramps are west-vergent. An E-vergent ramp anticline (structure E) is also observed. The spacing between adjacent ramp anticlines is about $8 \mathrm{~km}$ in this profile. Slope basins have formed behind many of the ramp anticlines. Deposition has accompanied the formation of these anticlines, as shown by progressively tilted reflectors in the slope basins (e.g. between $D$ and $E$ and between $F$ and $G$ in Fig. 4B). The thickness of the slope basin deposits could reach $1.5 \mathrm{~s}$ in two-way traveltime (or approximately $1.5 \mathrm{~km}$ ). A blind west-vergent frontal thrust (structure $\mathrm{C}$ ) located just to the east of the Penghu Channel marks the western limit of the compressional stress which has deformed the originally flat-lying sedimentary strata to form a ramp anticline, thus is 
interpreted as the deformation front of the accretionary wedge in this study.

In the offshore Tainan-Kaohsiung-Hengchun area, fold-and-thrust structures are buried beneath thick sedimentary strata, and diapiric anticlines become prominent features on the seismic profiles (Fig. 5). Diapiric anticlines can be easily identified by their acoustically amorphous character. Most of the diapiric anticlines are buried by young scdiments, but some have picrced through the sedimentary cover and become exposed on the sea floor. The Liuchiu Hsu islet sits on one of these diapiric anticlines that has been raised above the sea surface (structure $J$ in Fig. 5). Field observations show that these exposed diapiric anticlines consist mainly of deformed Pliocene mudstone (Huang, 1960; Chi, 1981).

Disturbance of the very young sedimentary strata on top of several diapiric anticlines suggests that they are still active. Muddy fluids emitted from active mud diapirs may form mud volcanoes on the sea floor. Fig. 6 is a $3.5 \mathrm{kHz}$ sub-bottom profile across one of the active mud volcano groups which is located on top of the Fangliao anticline to the west of the Fangliao Submarine Canyon (structure $K$ in Fig. 5).

The thickness of the sediments between mud diapiric ridges could reach $10,000 \mathrm{~m}$ (Sun and Liu, 1993). Many of the mud diapirs have moved up along thrust faults (e.g. diapirs $G$ and $I$ in Fig. 5). Due to rapid deposition of terrigenous sediments, most of the thrust faults do not extend upward to the sea floor. One W-vergent thrust fault which does extend to the sea floor (the bounding fault of diapir $\mathrm{G}$ in Fig. 5) can be structurally correlated to a major thrust fault bounding the Panpingshan anticline in the Kaohsiung area (Fig. 3).

Seismic profiles collected in the study area reveal that NNE-SSW trending fold-and-thrust structures observed in the Western Foothills onland Taiwan extend continuously to the offshore region underneath thick Coastal Plain and Kaoping shelf sediments. Fig. 7A shows a seismic profile located just offshore Tainan-Kaohsiung. Diapiric anti-

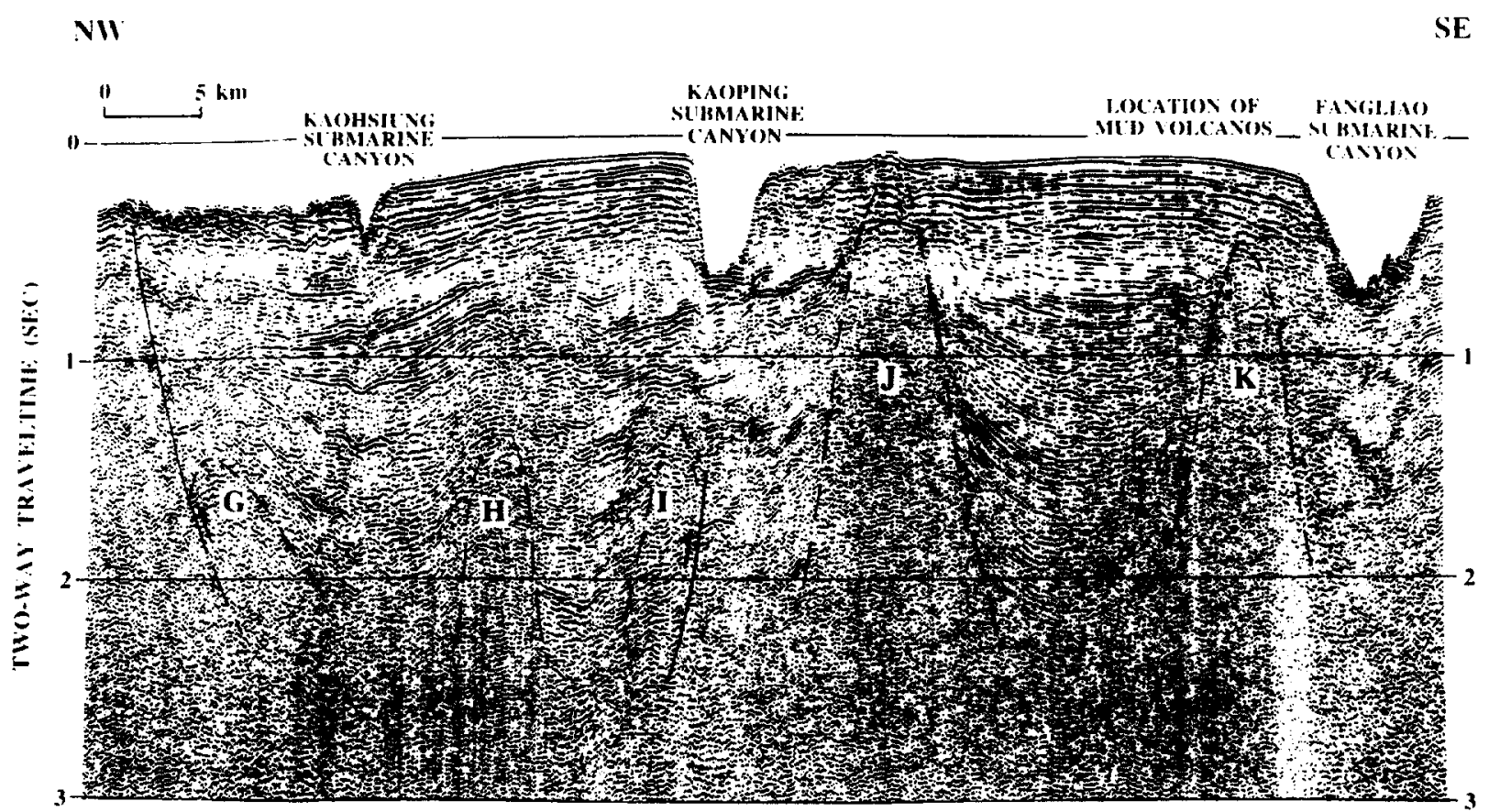

Fig. 5. Migrated single-fold seismic profile 320-30 to show the structural relationships of diapiric anticlines and submarine channels. Location is given in Fig. 3. $G$ is correlated to the Panpingshan anticline onland Taiwan. $J$ is the Liuchiu Hsu anticline. $K$ is the Fangliao diapiric anticline on top of which lies the active mud volcanoes shown in Fig. 6 . 


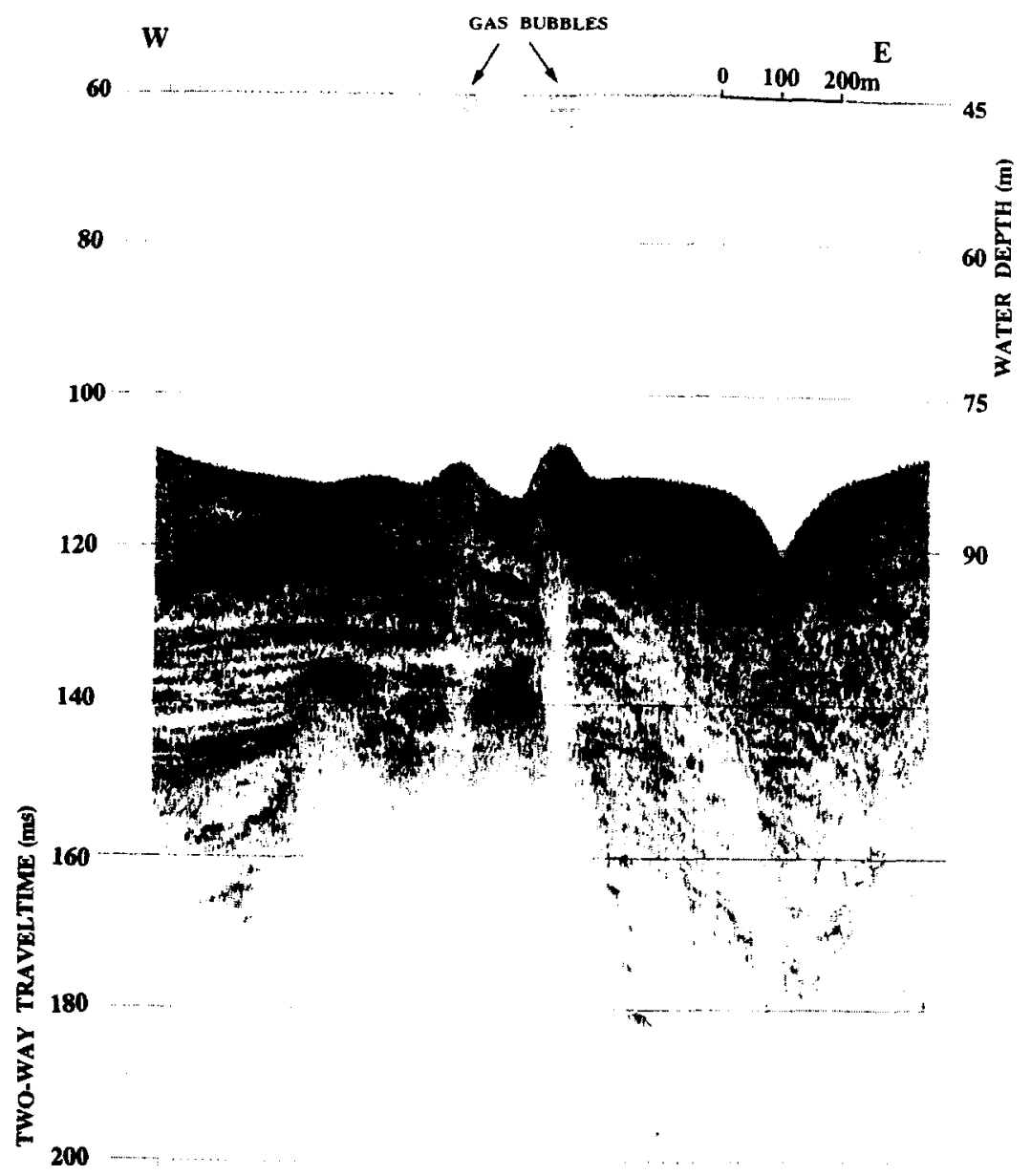

Fig. 6. A $3.5 \mathrm{kHz}$ profile across an active mud volcano group on top of the Fangliao diapiric anticline. Location is shown in Figs. 3 and 5 . Surface sediments have been disturbed by the mud fluids, and gas bubbles emitted from the active mud volcanos can be seen as strings of vertical dots directly above the mud volcanos.

clines observed on this profile can be easily correlated to the onland Tainan, Chungchou, and Panpingshan anticlines (Pan, 1968; Hsieh, 1972). Most of the diapiric anticlines in the area offshore southwestern Taiwan form NNE-SSW trending ridges, parallel the structural trend of the folds and thrust faults of the Western Foothills onland Taiwan (Huang, 1995).

\section{Discussions}

Due to the large amount of incoming orogenic sediments from the Taiwan mountain belt, the submarine accretionary wedge widens from south to north. The outgrowth of the accretionary wedge in the area off southwestern Taiwan has caused the westward migration of the Manila Trench as it approaches Taiwan, and turned the original NNE-SSW to N-S trends of the trench and lower slope domain structures into a NNW-SSE direction north of about $20^{\circ} \mathrm{N}$ (see inset map of Fig. 1). The structural trends mapped in the area off southwestern Taiwan reveal that the NNW-SSE trending lower slope domain structures observed by Reed et al. (1992) change gradually back to a NNE-SSW direction north of about $22^{\circ} \mathrm{N}$ (Fig. 3). This change can be explained by the influence of the Chinese continental margin geome- 
(A) 329-11

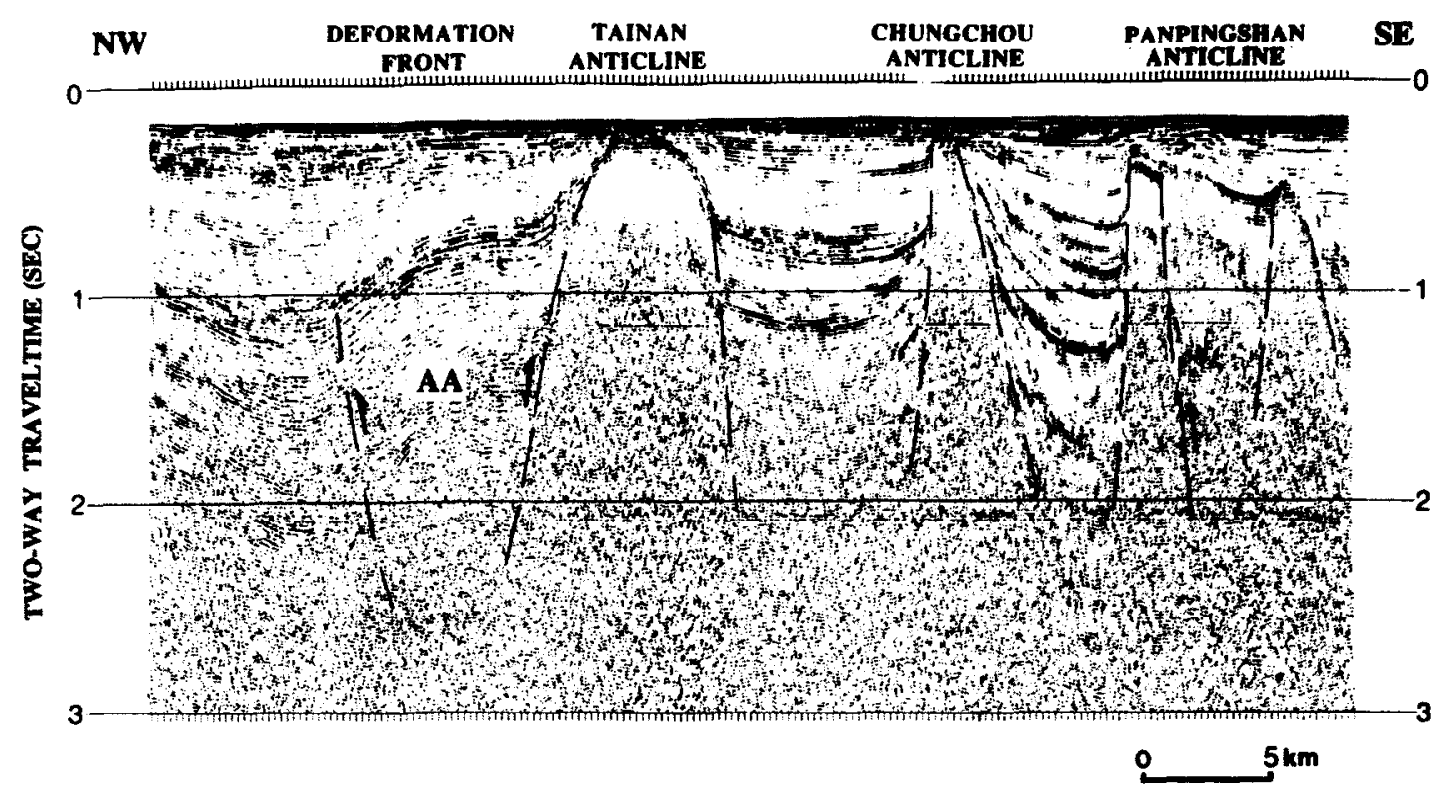

(B) $320-28$

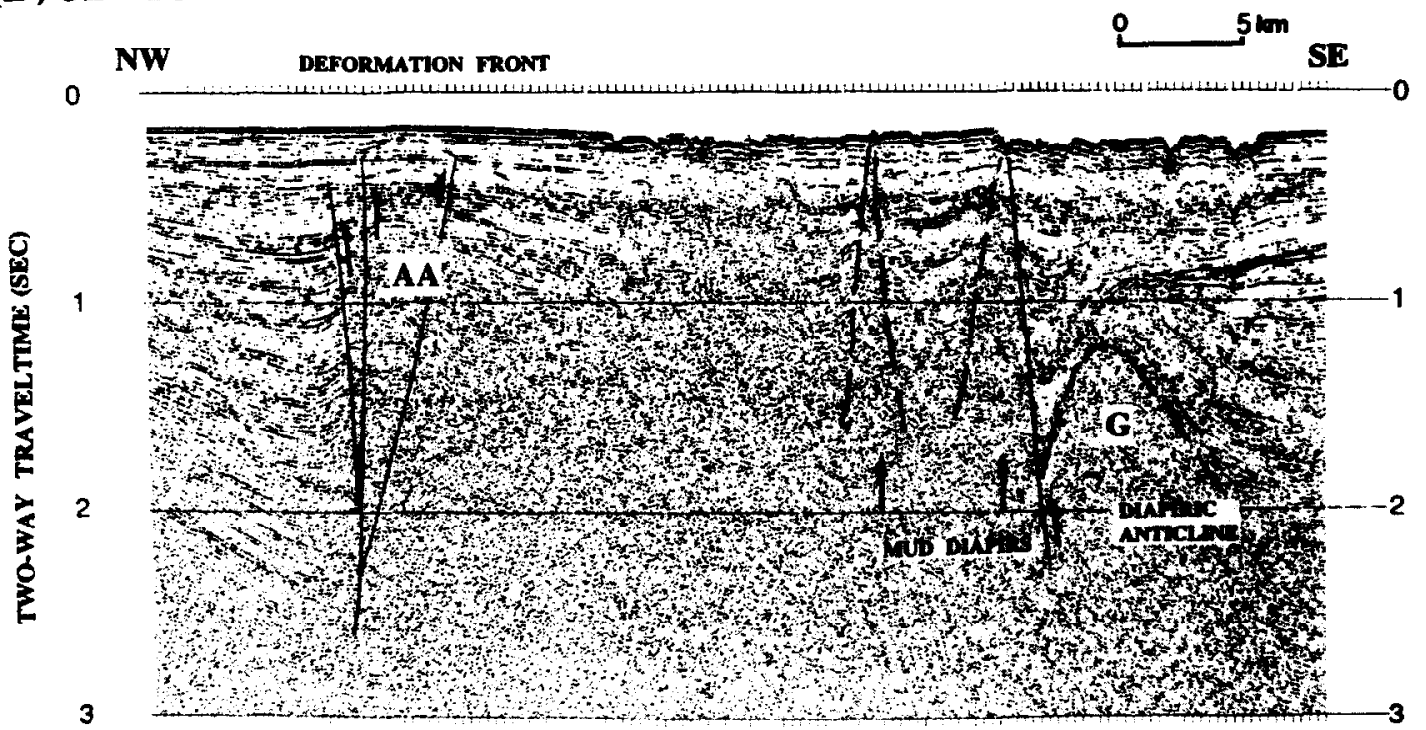

Fig. 7. (A) Migrated single-fold seismic profile 329-11. Location is shown in Fig. 3. Diapiric anticlines observed in this profiles are the offshore extension of the Panpingshan, Chungchou, and Tainan anticlines onland Taiwan. (B) Migrated single-fold seismic profile 320-28. Location is shown in Fig. 3. Diapiric anticline $G$ is the same structure $G$ as shown in Fig. 5. Seismic characters are very different across the structure $A A$ which is interpreted as the deformation front. 
try. The NE-SW trending Taiwan Strait shelf that comes into contact with the accretionary wedge offshore southwestern Taiwan acts as a rigid body which has prevented the westward migration of the accretionary wedge and resulted in a NE bending of the deformation front following the trend of the shelf edge.

The deformation front, defined as the location of the most frontal contractional structures along a convergent plate boundary, delineates the boundary of a convergent zone. In a typical subduction system, the deformation front generally follows the boundary between the trench and the accretionary wedge. Thus for the Luzon subduction system south of Taiwan, the Manila Trench is used to indicate the location of the deformation front. However, as the accretionary wedge approaches the Chinese continental slope and shelf, the Manila Trench gradually loses its morphological character. In the slope and shelf area where thick sedimentary cover has obscured the morphological and structural characteristics of the deformation front (Fig. 4A), the exact location of the deformation front becomes difficult to delineate.

In order to determine the most likely location of the deformation front in the slope and shelf region off southwestern Taiwan, we compiled a 3-D regional structural diagram based on the sea floor topography and seismic interpretations (Fig. 8). This map clearly shows that the NNW-SSE trending fold-and-thrust structures observed in the lower slope domain of the accretionary wedge south of Taiwan gradually bend toward the east as they extend toward the Chinese continental margin. Lee et al. $(1992,1993)$ suggest that the deformation front bends to the NE at $22^{\circ} 15 \mathrm{~N}$ and follows a trend of $\mathrm{N} 55^{\circ} \mathrm{E}$ to northwest of Kaohsiung City. The $\mathrm{N} 55^{\circ} \mathrm{E}$ trend of their deformation front is much sharper then the trend of the fold-and-thrust structures that appeared in Fig. 8. The structure representing the deformation front by Lee et al. (1992) is correlated to the thrust fault $G$ of Figs. 3, 5 and $7 B$ in this study. Since there are contractional structures to the west of thrust fault $G$, we propose that the location of the deformation front should lie further to the west then where suggested by Lee et al. $(1992,1993)$.

We suggest that the deformation front follows the northern extension of the Manila Trench in a $\mathrm{NW}-\mathrm{SE}$ direction to about $22^{\circ} \mathrm{N}$, then it gradually turns into NE-SW direction following the termination points of a series of W-vergent ramp anticlines that stacked up and terminated along the Chinese continental margin (Figs. 3 and 8). In the shelf region where the deformation front is difficult to recognize, the change of seismic character from continuous, coherent reflections of passive continental margin strata to chaotic, discontinuous reflections of disrupted and deformed strata could be used to delineate the location of the deformation front (Fig. 7). The slightly deformed upper strata of anticline AA as observed in profile $320-28$ (Fig. 7B) suggest that the normal fault bounded structure AA may have been reactivated due to the westward migration of the deformation front. The nature of this NE-SW trending reactivated fault system is probably transpressional dextral, as the velocity field of GPS stations reveal that the southwestern portion of Taiwan is moving southwestward relative to the fixed Asian continent ( $\mathrm{Yu}$ and Chen, 1994). This interpretation is also consistent with the "tectonic escape" model for the southwest Taiwan block proposed by Lu (1994). The deformation front extends to onland Taiwan near Tainan and may connect to the Hsinghua fault which is a right-lateral slip fault (Hsu and Chang, 1979).

\section{Conclusions}

Two distinctive structural patterns have been observed in the area offshore southwestern Taiwan. Normal faults which form horsts and grabens are observed in the shelf and slope regions of the passive Chinese continental margin located in the northwestern corner of the study area. Imbricated fold-and-thrust structures are observed in the lower slope domain of the submarine accretionary wedge. Structural patterns established from this study suggest that the NNW-SSE trending structures observed in the lower slope domain of the accretionary wedge south of Taiwan reorient gradually into a NNE-SSW direction in the offshore area of southwestern Taiwan (Figs. 3 and 8 ). The variation in structural trend is controlled by the geome- 


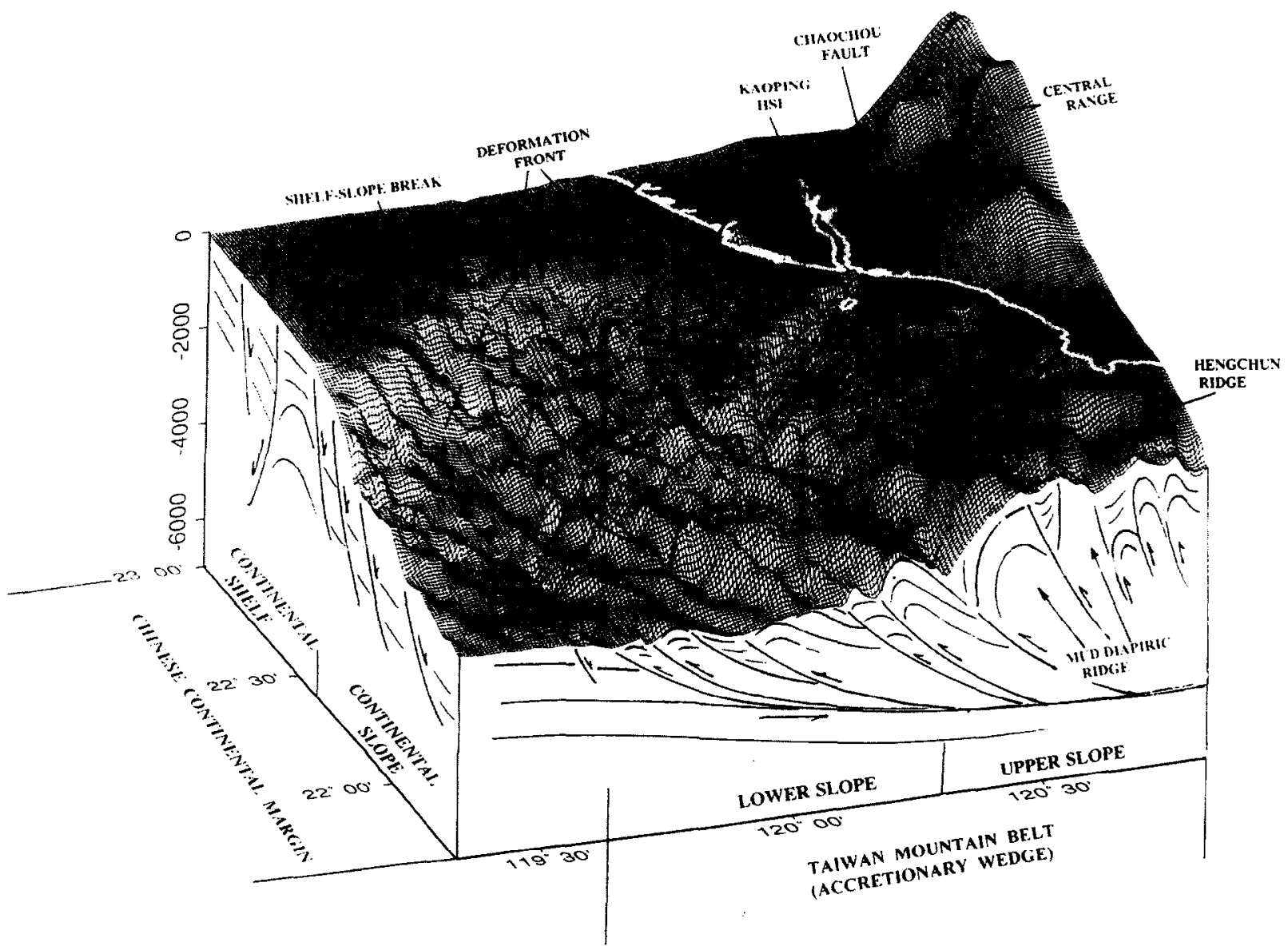

Fig. 8. A 3-dimensional structural interpretation of the Taiwan mountain belt for the area offshore southwestern Taiwan. Topographic relief of the anticlinal ridges in the lower slope domain indicates that the structural trend curves from NNW to NNE as these anticlinal ridges extended toward the Chinese continental margin. The overall structural pattern suggests that the deformation front aligns with the shelf-slope break as it approaches Tainan.

try of the Chinese continental margin basement. The frontal portion of the imbricated thrusts and related folds observed in the lower slope region of the accretionary wedge which extended northnorthwesterly toward Chinese continental margin were gradually buried and terminated as they reached the Chinese continental slope. The deformation front of the accretionary wedge extends northwestward along the Manila Trench and gradually retreated eastward following the termination of the fault-bend-anticlinal ridges along the continental slope, as the accretionary structures were obstructed by the thick continental crust. The $\mathrm{NE}-\mathrm{SW}$ trending section of the deformation front behaves as a dextral transcurrent fault toward Tainan and connects to the western frontal structures of the Taiwan mountain belt on land.

Structural features and deposition patterns observed in the area offshore southwestern Taiwan demonstrate that they are strongly controlled by the tectonic evolution of the arc-continent collision process. Furthermore, the geometry of the Asian continental margin also played an important role in shaping the structures of the deformation belt.

\section{Acknowledgement}

We wish to thank the captains, crew, and shipboard technicians of the $R / V$ Ocean Researcher $I$ 
and S.D. Chiou of the Ocean Research Vessels Instrument Center for their efforts in acquiring the data on which this study is based. Many of the data used in this study were collected in collaboration with H.S. Yu. The idea of initiating this study came during a discussion with $\mathrm{N}$. Lundberg and D. Reed. They have also kindly provided the bathymetric and seismic reflection data of MW9006 cruise. Discussions with S.C. Sun, H.S. Yu, T.Y. Lee, C.H. Chang, and Y.L. Yang during various stages of this study helped to clarify some of the ideas presented in this paper. Comments and suggestions made by D. Fisher, G.F. Moore, K.M. Yang and Y.Y. Hsu have greatly improved the manuscript. The viewing of multichannel seismic reflection profiles collected by the Chinese Petroleum Corp. (CPC) in the study area made available by H.S. Chung is greatly appreciated. Somc of the multichannel seismic reflection profiles used in this study were processed at the Geophysical Data Processing Center of the CPC under the directorship of F.C. Su. C.H. Chang processed most of the single-fold seismic refiection profiles using the SIOSEIS seismic data processing system. Y.F. Su, W.L. Huang and S.Y. Liu helped in compiling the bathymetric map and in preparing most of the figures used in this paper. This research was supported by the National Science Council of the Republic of China through grants NSC810209-M-002A-505 and NSC82-0209-M-002A-042.

\section{References}

Biq, C.C., 1972. Dual-trench structure in the Taiwan-Luzon region. Proc. Geol. Soc. China, 15: 65-75.

Bonilla, M.G., 1977. Summary of Quaternary faulting and elevation changes in Taiwan. Mem. Geol. Soc. China, 2: 43-55.

Bowin, C., Ru, R.S., Lee, C.S. and Schouten, H., 1978. Plate convergence and accretion in Taiwan-Luzon region. AAPG Bull., 62: 1645-1672.

Chai, B.H.T., 1972. Structure and tectonic evolution of Taiwan. Am. J. Sci., 272: 389-442.

Chi, W.R., 1981. Calcareous nannoplankton from the sediments of the Liuchiuhsu, southwestern Taiwan. Proc. Geol. Soc. China, 24: 141-147.

Ho, C.S., 1982. Tectonic evolution of Taiwan: Explanatory text for the tectonic map of Taiwan. Minist. Econ. Aff., Taipei, 126 pp.
IIo, C.S., 1986. A synthesis of the geological evolution of Taiwan. Tectonophysics, 125: 1-16.

Hsieh, S.H., 1972. Subsurface geology and gravity anomalies of the Tainan and Chungchou structures of the Coastal Plain of southwestern Taiwan. Pet. Geol. Taiwan, 10: 323-338.

Hsu, T.L. and Chang, H.C., 1979. Quaternary faulting in Taiwan. Mem. Geol. Soc. China, 3: 155-165.

$\mathrm{Hu}, \mathrm{C.C}, \mathrm{1988}$. Basement structure and the Oligocene to Miocene stratigraphy of the Tainan Basin. Petroleum, 24(4): 104-115 (in Chinese).

Huang, I.L., 1993. Structural styles offshore southwestern Taiwan. Thesis. Dep. Geol., Natl. Taiwan Univ. (in Chinese).

Huang, T.Y., 1960. The foraminifera from the Liuchiuhsu mudstone of Liuchiuhsu off the southwestern coast of Taiwan. Proc. Geol. Soc. China, 3: 59-66.

Huang, W.L., 1995. Distribution of the mud diapirs offshore southwestern Taiwan, their relationships to the onland anticlinal structures and their effects on the deposition environment in southwestern Taiwan. Thesis. Inst. Oceanogr., Natl. Taiwan Univ. (in Chinese).

Kuang, M.Y. and Wu, S.C.S., 1986. Hydrocarbon potential in western Taiwan. Pet. Geol. Taiwan, 22: 201-226.

Lee, T.Y., Tang, C.H. and Hsu, Y.Y., 1992. Structural geometry of the deformation front between $22^{\circ} \mathrm{N}$ and $23^{\circ} \mathrm{N}$, offshore southeastern Taiwan arc-continent collision zone. EOS Trans. AGU, 73: 539.

Lee, T.Y., Tang, C.H., Ting, J.S. and Hsu, Y.Y., 1993. Sequence stratigraphy of the Tainan Basin, offshore southwestern Taiwan. Pet. Geol. Taiwan, 28: 119-158.

Letouzey, J. and Sage, L., 1988. Geological and Structural Map of Eastern Asia. AAPG, Tulsa, OK.

Liu, C.S., 1992. Recent development of marine geophysical exploration capabilities in Taiwan. Ocean Res., 14: 217-231.

Liu, C.S., Liu, S.Y., Kuo, B.Y., Lundberg, N. and Reed, D., 1992. Characteristics of the gravity and magnetic anomalies off southern Taiwan. Acta Geol. Taiwan., 30: 123-130.

Liu, C.S., Liu, S.Y., Song, G.S., Shyu, C.T., Yu, H.S., Chiao, L.Y., Wang, C.S. and Karp, B., 1996. Digital bathymetry data offshore Taiwan. In: Annu. Meet. Geol. Soc. China, Progr. with Abstracts, Taipei, pp. 420-425.

Liu, C.S., Lundberg, N., Reed, D.L. and Huang, Y.L., 1993. Morphological and seismic charactenstics of the Kaoping Submarine Canyon. Mar. Geol., 111: 93-108.

Lu, C.Y., 1994. Neotectonics in the foreland thrust belt of Taiwan. Pet. Geol. Taiwan, 29: 1-26.

Lu, C.Y. and Hsu, K.J., 1992. Tectonic evolution of the Taiwan mountain belt. Pet. Geol. Taiwan, 27: 21-46.

Lundberg, N., Reed, D.L. and Liu, C.S., 1991. The submarine propagation tip of the Taiwan collision: Shallow crustal structure and orogenic sedimentation. In: TAICRUST Workshop Proc., Natl. Taiwan Univ., Taipei, pp. 93-102.

Lundberg, N., Reed, D., Liu, C.S. and Lieske Jr., J., 1992. Structural controls on orogenic sedimentation, submarine Taiwan collision. Acta Geol. Taiwan., 30: 131-140.

Pan, Y.S., 1968. Interpretation aid seismic coordination of the Bouguer gravity anomalies obtained in southern Taiwan. Pet. Geol. Taiwan, 6: 197-207. 
Reed, D., Lundberg, N., Liu, C.S. and Kuo, B.Y., 1992. Structural relations along the margins of the offshore Taiwan accretionary wedge: Implications for accretion and crustal kinematics. Acta Geol. Taiwan., 30: 105-122.

Sun, S.C., 1982. The Tertiary basin of offshore Taiwan. Proc. 2nd ASCOPE Conf. Exhibition, 1981, Manila, pp. 126-135.

Sun, S.C., 1985. The Cenozoic tectonic evolution of offshore Taiwan. Energy, 10: 421-432.

Sun, S.C. and Liu, C.S., 1993. Mud diapirs and submarine channel deposits in offshore Kaohsiung-Rengchun, southwest Taiwan. Pet. Geol. Taiwan, 28: 1-14.

Suppe, J., 1984. Kinematics of arc-continent collision, flipping of subduction, and back-arc spreading near Taiwan. Mem. Geol. Soc. China, 6: 21-34.

Teng, L.S., 1990. Late Cenozoic arc-continent collision in Taiwan. Tectonophysics, 183: 57-76.

Tsao, C.Q. and Chang, M., 1988. Study of petroleum potential in Oligocene sandstone of Tainan Basin. Min. Metall., 33: 49-57 (in Chinese).

Yang, K.M., Ting, H.H. and Yuan, J., 1991. Structural styles and tectonic modes of Neogene extensional tectonics in southwestern Taiwan: Implications for hydrocarbon exploration. Pet. Geol. Taiwan, 26: 1-31.

Yang, K.M., Chi, W.R., Wu, J.C. and Ting, H.H., 1994. Tectonic evolution and mechanisms for formations of Neogene extensional basin in southwestern Taiwan: Implications for hydrocarbon exploration. Ann. Meet. Geol. Soc. China, Progr. with Abstr., March 1994, Taipei, pp. 392-395.

Yu, H.S. and Liu, C.S., 1996. Geology of submarine canyons off southwestern Taiwan coast. Mar. Geol., in press.

Yu, H.S. and Wen, Y.H., 1992. Physiographic characteristics of the continental margin off southwestern Taiwan. J. Geol. Soc. China, 35: 337-351.

Yu, S.B. and Chen, H.Y., 1994. Global Positioning System measurements of crustal deformation in the Taiwan arc-continent collision zone. TAO, 5: 477-498.

Wessel, P. and Smith, W.H.F., 1991. The GMT-System Version 2.0, Technical Reference and Cookbook. Scripps Inst. Oceanogr., Univ. Calif., San Diego. 